\title{
Peridotite xenoliths from Porcupine Dome, Montana, USA: Depleted subcontinental lithosphere samples in an olivine-phlogopite-carbonate magma
}

\author{
Hearn, B. Carter, Jr. 1

\section{US Geological Survey 954, Reston VA 20192, USA}

Porcupine Dome in southeastern Montana is a broad gentle uplift about 50 ? $\mathrm{km}$ in diameter, which exposes Cretaceous marine sedimentary rocks and is underlain by uplifted Precambrian basement rocks of the Archean Wyoming Craton. Igneous bodies occur in a zone that is $45 \mathrm{~km}$ long, about 5 $\mathrm{km}$ wide, and is aligned N $45 \mathrm{E}$. The zone includes, from west to east, the Froze-to-Death Butte diatreme and plug, the Ingomar dikes (Geyser Springs dikes of Doden and Gold, 1993b, and Mitchell and Bergman, 1991) on Ingomar dome, the Johnson Ranch diatreme, the Gold Butte diatreme and plug, and the Stellar Creek Butte diatreme. Co-linear dikes with trends N $68 \mathrm{E}$ to E-W are associated with the latter three diatremes. Small breccia masses occur locally along the dikes. The Johnson Ranch diatreme contains large descended xenoliths of Paleocene sedimentary rocks (based on pollen analysis) and probable Eocene sedimentary rocks (based on lithology), which suggests a post-early Eocene age for the igneous bodies. K/Ar dating attempts have been unsuccessful. Marvin et al (1980) determined a phlogopite age of 78.6 Ma that exceeds the probable Eocene age based on sedimentary xenoliths, and indicates the presence of excess argon. Mitchell and Bergman (1991) report that Ar 40/39 analysis gave a total gas age of $91.6 \mathrm{Ma}$ with no plateau.

Partially altered peridotite xenoliths as large as $8 \times 5 \times 3 \mathrm{~cm}$ occur in the Froze-to-Death Butte diatreme and in the Ingomar dikes. Sixteen of fifty peridotite xenoliths are garnet-bearing in the Froze-toDeath Butte suite. Sparse crustal gneiss and granulite xenoliths also occur. Garnet and ilmenite xenocrysts, and ilmenite and olivine megacrysts occur in Froze-to-Death Butte, the Ingomar dikes, and in the Johnson Ranch diatreme.. In garnet-, garnet-spinel, and spinel-bearing peridotite xenoliths, olivines and orthopyroxenes have been completely altered to calcite, dolomite, and fine-grained quartz, but garnet, spinel and clinopyroxene survive. Distinctive textures of pseudomorphed olivines and orthopyroxenes show that the suite is dominantly coarse granular and harzburgitic in composition. Some altered spinel peridotites appear to have been finer-grained, with lensoid spinels, and may represent a foliated spinel peridotite suite. Phlogopite occurs as rims around garnets and as isolated grains, and indicates later metasomatism of chemically depleted harzburgites, a common feature in continental lithospheric mantle samples.

In peridotite xenoliths, garnets are Cr-pyropes (purple and red, $\mathrm{Cr} 2 \mathrm{O} 3$ 3.2-9.0 wt \%, Mg\# 80.787.5); clinopyroxenes are Cr-diopsides ( $\mathrm{Cr} 2 \mathrm{O} 3$ 1.5-3.0), and spinels are $\mathrm{Cr}$-rich ( $\mathrm{Cr} 2 \mathrm{O} 3$ 54.5-59.7). Most xenolith $\mathrm{Cr}$-pyropes are in the G9 (lherzolitic) compositional range; only one xenolith garnet has marginal $\mathrm{G} 10$ composition with $\mathrm{CaO}$ below the Gurney $85 \%$ line.

Xenocryst garnets are in three groups: Cr-pyropes (purple and red, Cr2O3 2.1-8.1, Mg\# 77.0-85.6),

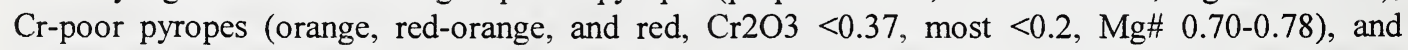

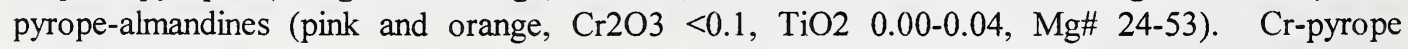
xenocrysts have G9 compositions, of peridotitic derivation. The pyrope-almandines are probably derived from crustal rocks. In comparison, the $\mathrm{Cr}$-poor pyropes have higher $\mathrm{TiO} 2$ contents $(0.34-$ 1.5) and $\mathrm{Na} 2 \mathrm{O}$ contents (0.04-0.12) which may indicate affinity with $\mathrm{Cr}$-poor megacryst garnets which are common in many kimberlites, but have not been found in the Porcupine Dome occurrences. Alternatively, the $\mathrm{TiO} 2, \mathrm{Cr} 2 \mathrm{O} 3$, and $\mathrm{Na} 2 \mathrm{O}$ contents might fit an eclogitic source, but $\mathrm{MgO}$ is higher and $\mathrm{CaO}$ is lower than in most eclogitic garnets (Schulze, 1993; Gurney and Moore, 1993). 
Nearly all of the olivine megacrysts are completely pseudomorphed by carbonates and quartz; one contains patches of surviving olivine of Fo79 composition, low enough to suggest cognate affinity with the host magma. Ilmenite xenocrysts and megacrysts are single crystals or multi-grain mosaics, Mg-rich (MgO 7-12), low in $\mathrm{Nb2O}$ (0.12-0.33), and low in calculated $\mathrm{Fe} 2 \mathrm{O} 3$, values which are in the compositional range for kimberlitic ilmenites. $\mathrm{Cr} 2 \mathrm{O} 3$ contents (0.04-1.0) are lower than in most kimberlitic ilmenites, but are similar to low-Cr ilmenites in the A4 and other kimberlites, Ontario (Schulze et al, 1996). Ilmenites in two altered olivine megacrysts or ilmenite-bearing dunites have compositions similar to the megacrysts and xenocrysts; neither is associated with fresh olivine.

Calculated temperatures of clinopyroxenes range from 990 to $1100{ }^{\circ} \mathrm{C}$ by the Finnerty and Boyd (1987) method. For two garnet-spinel peridotites, calculated pressures by the O'Neill (1981) method are 4.1 GPa for their clinopyroxene temperatures of 1070 and $1100{ }^{\circ} \mathrm{C}$. The overall temperature range, assuming pressure of $4.1 \mathrm{GPa}$ for the other xenoliths, is in the diamond stability field and near an assumed shield geotherm. Criteria that favor diamond potential are the T-P range, ilmenite compositions, and some spinel compositions, but the lack of G9 garnets suggests that diamond potential is low. A similar conclusion was reached by Doden and Gold (1993a) on the basis of xenocryst compositions.

The host magmas contain phlogopite and abundant olivine phenocrysts in a groundmass that is carbonate-rich, with phlogopite, apatite, Ti magnetite, and perovskite(?). Some of the larger phlogopites may be xenocrystic. Chondrite-normalized REE patterns are light REE enriched, steep, and linear, similar to those of alkalic ultramafic rocks, kimberlites, and carbonatites. These magmas have been termed carbonate-rich mica peridotites (Hearn, 1989), lamprophyres (Doden and Gold, 1993b), and lamproites (Mitchell and Bergman, 1991). The rocks show similarities to aillikite, a rather vaguely defined porphyritic ultramafic rock which consists of olivine and phlogopite phenocrysts in a carbonate-rich groundmass, and for which the type locality is Aillik Bay, Labrador, Canada (Malpas, Foley, and King, 1986). In fresh igneous rock from the Gold Butte plug, olivines are Fo 84-89, and lath-shaped calcites suggest crystallization from a melt. Phlogopite phenocrysts are Ti-, Ba- and F-bearing and low in $\mathrm{Cr} 2 \mathrm{O} 3$ ('TiO2 1.6-3.6, $\mathrm{BaO}$ 0.05-1.6, F 0.34-0.74, $\mathrm{Cr} 2 \mathrm{O} 3$ 0.00-0.37). Groundmass phlogopite compositions are similar to phenocryst rims. The Porcupine Dome magmas are closely similar to olivine-rich and carbonate-rich magmas that produced diatremes and dikes in the Grassrange area of central Montana, and to some magmas in the Missouri River Breaks area of north-central Montana (Hearn, 1989). Such very fluid magmas are ideally suited for differentiation by several mechanisms: crystal settling of olivine and phlogopite, filter pressing, or silicate-carbonate liquid immiscibility. Field evidence for such processes includes ribbon-textured dikes with subparallel carbonate dikelets and carbonate patches (dominantly calcite and dolomite, with traces of phlogopite, apatite, and $\mathrm{Ti}$ magnetite), and segregation textures. The carbonate dikelets are equivalent to carbonatites in major and minor element compositions and mineralogy, and thus are evidence for derivation of carbonatites at shallow depths from alkalic ultramafic magmas. Similar mechanisms may have produced rare carbonatitic dikes that are associated with diatremes in the Missouri Breaks area of north-central Montana (Hearn, 1989).

\section{References}

Doden, A.G., and Gold, D.P., 1993a, Kimberlite xenocrysts from the Porcupine Dome diatremes, east-central Montana: Evidence for multiple sources of garnet and evaluation of diamond potential: Geol. Soc. America, Abstracts with Programs, v. 25, p. 98.

Doden, A.G., and Gold, D.P., 1993b, Diatreme-dike associations of central Montana, in Hunter, L.D.V., ed., Energy and Mineral Resources of Central Montana: Montana Geol. Soc., 1993 Field Conf. Guidebook, p. 215-226. 
Finnerty, A.A., and Boyd, F.R., 1987, Thermometry for garnet peridotites: Basis for the determination of thermal and compositional structure of the upper mantle, in Nixon, P.H., ed., Mantle Xenoliths: Chichester, John Wiley and Sons, p. 381-402.

Gurney, J.J., and Moore, R.O., 1993, Geochemical correlations between kimberlitic indicator minerals and diamonds: in Diamonds: Exploration, Sampling and Evaluation, Prospectors and Developers Association of Canada, Short Course, Toronto, Canada, p. 147-171.

Hearn, B.C., Jr., 1989, Alkalic ultramafic magmas in north-central Montana, USA: Genetic connections of alnoite, kimberlite, and carbonatite, in Jaques, A.L., Ferguson, J., and Green, D.H., eds., Kimberlites and Related Rocks - Volume 1 Their Composition, Occurrence, Origin, and Emplacement: Geol. Soc. Australia, Spec. Publ. 14, p. 109-119.

Malpas, J., Foley, S.F., and King, A.F., 1986, Alkaline mafic and ultramafic lamprophyres from the Aillik Bay area, Labrador: Can. Jour. Earth Science, v. 23, p. 1902-1918.

Mitchell, R.H., and Bergman, S.C., 1991, Petrology of lamproites: New York, Plenum Press, 447 p.

O'Neill, H.St.C., 1981, The transition between spinel lherzolite and garnet lherzolite, and its use as a geobarometer: Contrib. Mineral. Petrol., v. 77, p. 185-194.

Schulze, D.J., 1993, Garnet xenocryst populations in North American kimberlites: in Diamonds: Exploration, Sampling and Evaluation, Prospectors and Developers Assoc. of Canada, Short Course, Toronto, Canada, p. 361-377.

Schulze, D.J., Anderson, P.F.N., Hearn, B.C., Jr., and Hetman, C.M., 1996, Origin and significance of ilmenite megacrysts and macrocrysts from kimberlite: Internat. Geology Review, v. 37, p. 780812. 